ALEKSANDAR MEDOVIĆ

Museum of Vojvodina

Novi Sad, Serbia

E-mail: aleksandar.medovic@muzejvojvodine.org.rs
Received: January $18^{\text {th }} 2021$

Accepted: November $20^{\text {th }} 2021$

Original research article

904:725.826"652"(497.11)

902.2:691.11(497.11)

COBISS.SR-ID 55382281

https://doi.org/10.18485/arhe_apn.2021.17.3

\title{
DOES HISTORY REPEAT ITSELF? THE DETERMINATION OF WOOD SPECIES USED FOR THE CONSTRUCTION OF THE VIMINACIUM AMPHITHEATRE
}

\begin{abstract}
The wooden amphitheatre of Viminacium is mainly made of beech timber. Hornbeam, ash, maple, oak and coniferous wood were also used for the construction. It is considered that beech was underrated in Roman times and mostly used as firewood, however, recent anthracological research in the region has revealed that it was also used in shipbuilding. A great variety of tree species was available in Rome in large quantities. However, the high demand for timber in Rome led to the rapid depletion of the woodlands surrounding the capital and in much of the Apennines. As the empire expanded, timber cutting continued and expanded abroad, leading to timber being transported over long distances within and between the Roman provinces. Oak has always had enormous value, not only in Roman times but also throughout history. It was considered a high-quality construction timber. According to a forest regulation document of the Military Frontier from the $18^{\text {th }}$ century, the use of oak for the construction of public buildings was prohibited by Austrian imperial authorities. The regulation indicates, on the one hand, that the selective felling of oak trees led to a change in the structure of the remaining forests in the region and to an increase in the depletion of the forest and, on the other hand, oak, due to its weight, was prone to causing damage to the buildings. As these buildings had to be made of quality wood, everything except the roof needed to be built of "white wood", i.e. beech, ash, or hornbeam.
\end{abstract}

\section{KEYWORDS: VIMINACIUM, ROMAN PERIOD, AMPHITHEATRE, WOODEN CONSTRUCTION, ANTHRACOLOGY.}

\section{INTRODUCTION}

Viminacium is located on the southern border of the Pannonian plain, in today's Serbia, at the confluence of the Mlava and Danube rivers (Fig. 1). It was situated in the province of Moesia, Moesia Superior, later Moesia Prima. Initially, it was a military camp, where the legion VII Claudia was stationed from the second half of the $1^{\text {st }}$ century AD (Bogdanović and Nikolić, 2017). Next to the camp, a city developed and became the capital of the province. The Viminacium amphitheatre was situated near the legionary fortress. Based on archaeological data, it can be assumed that the amphithe- atre was built at the beginning of the $2^{\text {nd }}$ century $\mathrm{AD}$, during the reign of the emperor Trajan. It was used until the end of the $3^{\text {rd }}$ or early $4^{\text {th }}$ century AD.

It has been possible to distinguish the primary wooden structure that was later replaced by a stone and wooden amphitheatre. The wooden amphitheatre of Viminacium represents that of a typical construction of an Imperial military type and typologically it belongs to Golvin's simplest type of amphitheatre (Golvin, 1988). The Viminacium wooden amphitheatre had at least 11 tiers of seats and could accommodate a maximum of 6,000 spectators (Bogdanović and Nikolić, 2017). Archaeologists assume that the length of the orig- 


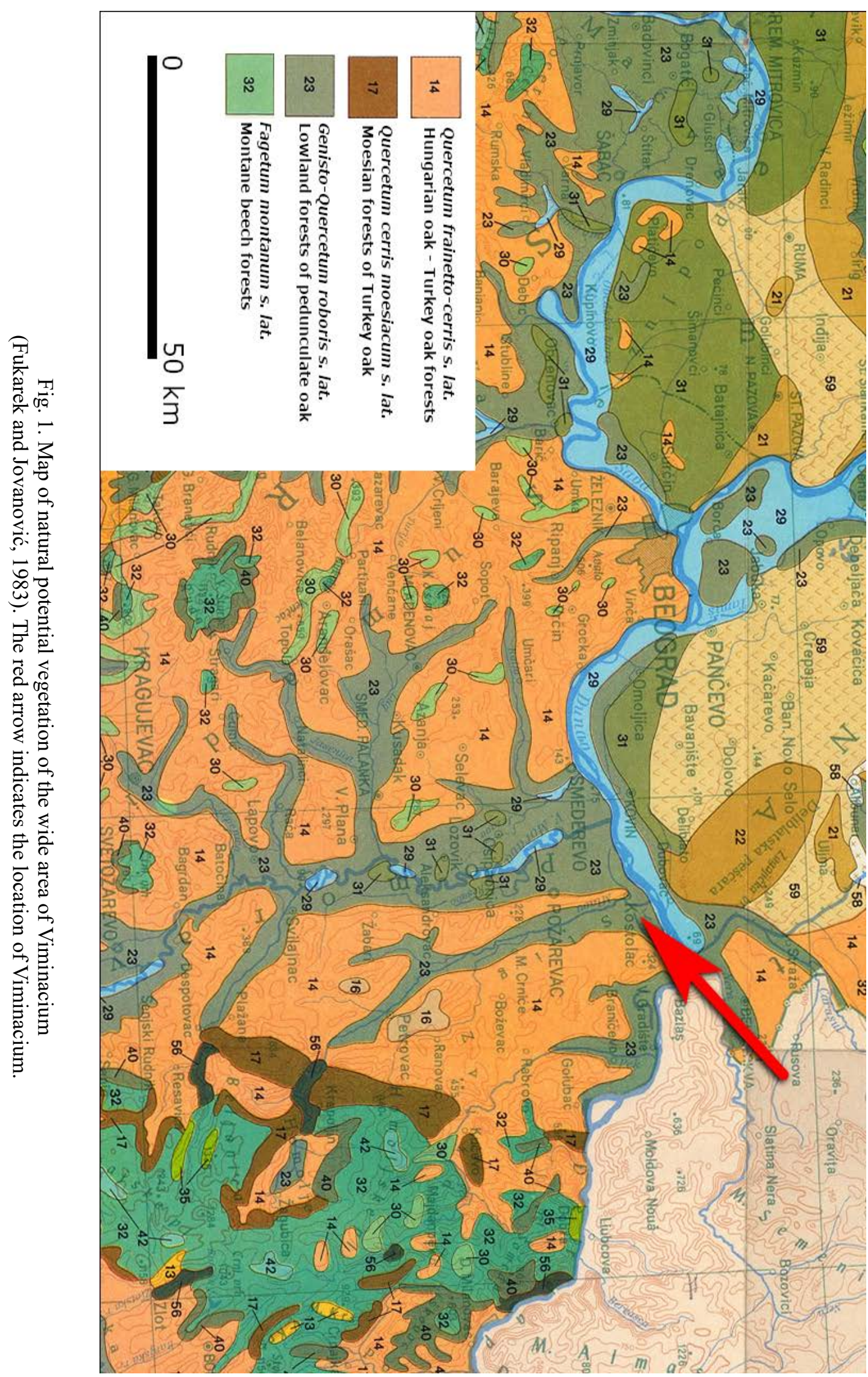


inal timber amphitheatre was approximately $82 \mathrm{~m}$ and the width was c. $70 \mathrm{~m}$. The structural evidence for this primary structure includes post-holes and beam-slots detected at both ends of the long axis of the building and in the north-eastern part of the excavated surface (Bogdanović and Nikolić, 2017). Also, some pits with traces of timber construction, which were identified within the southern and south-western parts, belong to the wooden building. It is estimated that the seating framework consisted of wooden seats that were mounted on a wooden framework that was supported by wooden beams. Archaeologists have concluded that the full width of the cavea measured approximately $11 \mathrm{~m}$. The whole complex structure was built on the principle of simple components representing trestles.

\section{MATERIAL AND METHODS}

Wood is preserved over a long period only in very humid or very dry locations, at very low temperatures, in contact with metal, or in the form of charcoal (Bernabei et al., 2019). The latter prevails in Serbian archaeology. Uncharred wood may also occur in historical layers, mainly in Middle Age pits.

Seventeen samples of soil containing plant material needed for macro botanical analyses were collected from pits and postholes during the excavation of the amphitheatre, mostly during the 2011 campaign (Table 1). Manual flotation of the samples (0.5-6 litres of substratum per sample) was carried out in the Museum of Vojvodina, Novi Sad. The plant material, consisting mainly of carbonized wood, was dried slowly for several days in a dry, dark place to be analysed later using low power $(7 x-45 x)$ microscopes. The identification of charred and uncharred wood was assisted by wood anatomy keys, both online and printed versions (Schoch et al., 2004; Schweingruber, 1990). Five samples contained a considerable number of taxa of crops, weeds, and ruderals, but an insignificant amount of charred and uncharred items (Medović, 2014). It is considered that they had been moved, postdepositionally, from their original location.

\section{RESULTS}

\section{Overview of the Charcoal Assemblages}

A total of 311 charred fragments $(308,099 \mathrm{mg})$ were examined and 12 different taxa were identified, two to a species level and five to a genus level. A total of 11 uncharred wood fragments (29796 $\mathrm{mg}$ ) were singled out and identified to the pinoid clade of Pinaceae (conifers with resin canals). The most dominant species in the assemblage is beech; its wood accounts for more than $2 / 3$ of the charred wood assemblage weight (see Table 1). The finds of hornbeam, maple, and ash exceed 1 percent by weight, respectively. However, seven detected taxa are below this limit. Among these, the most prominent are willow/poplar, oak, elm, and coniferous wood. Beechwood was found in 3/4 of all samples, hornbeam, and ash in every second sample, and oak fragments in every third sample.

Fragments successfully identified to at least the family level varied in size from $2 \mathrm{~mm}$ to $40 \mathrm{~mm}$ in the transverse dimension. In most archaeological wood charcoal assemblages, $<2 \mathrm{~mm}$ fragments rarely have enough anatomical features preserved to permit botanical identification (Kabukcu, 2018).

Based on qualitative ring curvature estimation criteria (Marguerie and Hunot, 2007), on most charred wood fragments weakly curved rings (the rings seem "straight" and the rays parallel) and moderately curved rings could be observed. This suggests the use of large pieces of wood such as trunks or large branches. Also, few fragments of branches could be observed: 6 Fagus cf. moesiaca (2-3 cm radius), 3 Carpinus betulus (1.5-2 cm radius), and 1 Acer ( $3 \mathrm{~cm}$ radius). Small branches and twigs could not be observed. 


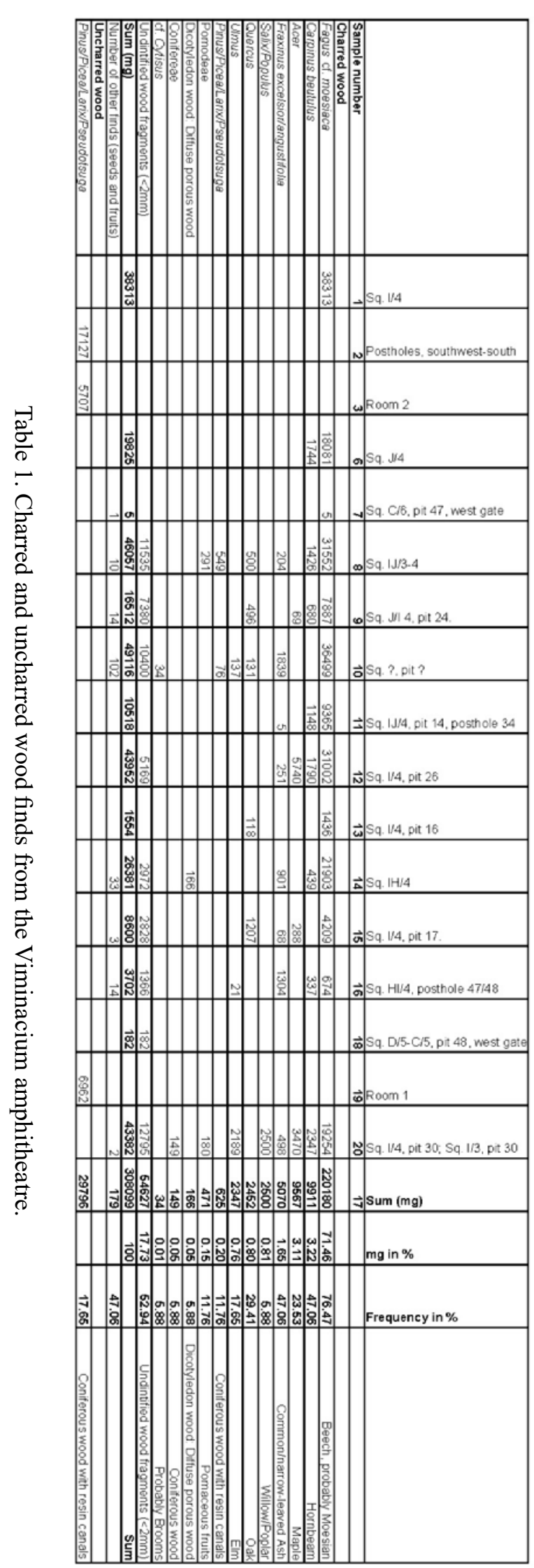

\section{Forests of north-eastern Serbia}

A climatogenic forest typical for Serbia is a Hungarian oak and Turkey oak forest (Quercetum frainetto-cerris Rud. 49 s. 1.) (Vukin and Rakonjac, 2013). It is considered to be its coeno-ecological synonym (Fig. 1).

Today, however, beech forests are the most widespread forests in Serbia and cover 29.3\% of the total forest area (Banković and Ranković, 2009). Three beech species grow in Serbia: Moesian beech (Fagus moesiaca (Domin, Maly) Czeczott), European beech (Fagus sylvatica L.) and Oriental beech (Fagus orientalis Lipsky) (Cvjetićanin, 2003).

Wood anatomy does not permit a distinction between the different species of Fagus. Moesian beech is the most widespread tree species in Serbia, with the widest altitudinal range (40-1,800 masl) (Cvjetićanin, 2003). Therefore, we assume that the charred wood of beech in charcoal assemblages from Viminacium amphitheatre belongs to Moesian beech.

It has been estimated that at the beginning of the $19^{\text {th }}$ century, 80 percent of Serbian territory was covered in forest. The French poet and politician Alphonse Marie Louis de Lamartine, who in 1833 (De Lamartine, 1843) travelled through central Serbia for six days, remarked on an "ocean" of "virgin forests" with "magnificent and perpetual umbrages with no other spectacle than the endless colonnades of enormous and lofty trunks of beech, the waves of foliage swayed by the winds, [and] the avenues of hills and mountains in the uniform garb of their secular oaks".

Bertrandon de la Broquiere, a councillor to the ruler of Burgundy in the $15^{\text {th }}$ century, commented on the Central Balkans as a "well-inhabited country", with many villages and good food and wine. This reflected the large colonisation that had transformed the Mačva plain, the Morava Valley, and the right bank of the Middle Danube into a densely populated region (Halpern, 1999). 
The cyclical expansion and decrease of forests in the region of today's Serbia are directly related to the increase and decrease of the population through the centuries. In times of prosperity, the forests were heavily cut as a direct result of recolonisation and increased demand for agricultural land. In a few extreme cases, war has helped forests by allowing ecosystems to recover free from human pressure, e.g. The Hundred Years' War between England and France in the $14^{\text {th }}$ century (Food and Agriculture Organization of the United Nations, 1995), or the Great Migrations of the Serbs - two large migrations from various territories under the rule of the Ottoman Empire to regions under the rule of the Habsburg Monarchy in the $17^{\text {th }}$ and the $18^{\text {th }}$ centuries. In Serbia, Hungarian oak, and Turkey oak forests are the most vulnerable to anthropogenic changes (Stojanović, 2007).

Andrew Archibald Paton, a consul-general in Serbia, travelled, during the years 1843 and 1844 , through the countryside of Serbia. He left some interesting remarks on soil quality and its relationship to forests in the surrounding area of Viminacium (Paton, 1845): “The soil at Posharevatz (Požarevac) is remarkably rich, the greasy humus being from fifteen to twenty-five feet thick, and consequently able to nourish the noblest forest trees. In the Banat, which is the granary of the Austrian empire, trees grow well for fifteen, twenty, or twenty-five years, and then die away. The cause of this is, that the earth, although rich, is only from three to six feet thick, with sand or cold clay below; thus as soon as the roots descend to the substrate, in which they find no nourishment, rottenness appears on the top of the branches, and gradually descends". This is not the only source that indicates the poor quality of trees in the Pannonian Plain along the Danube. The statistical report of the Imperial Austrian Army from 1807 states (Demian, 1807): "The local forests are near Gardinovci, Kovilj, and Kać, in which oak and elm are the predominant species of wood, but they are of poor quality, as most of the trunks are gnarled and rotten and therefore only suitable for firewood".

\section{Timber economy in the Roman Age}

A great variety of tree species was available in Rome in large quantities: ebony (Diospyros spp.), cedar (Cedrus spp.), box (Buxus sempervirens L.), terebinth (Pistacia terebinthus L.), holm oak (Quercus ilex L.), and many others. Patrician houses commonly contained a wide choice of wood (Bernabei et al., 2019). For the construction of buildings, silver fir (Abies alba) was the preferred tree species (Bernabei et al., 2019; Moser et al., 2013). The Romans had an extensive knowledge of the technological properties of wood. Vitruvius, in his treatise on architecture (De Architectura, II, chap. 9-10), indicates the characteristics that make silver fir particularly valuable: its light wood and a large, regular stem. Archaeological finds in Pompeii, Herculaneum, and Oplontis (Moser et al., 2018, 2013, 2011) confirm this. The favourite timber for building was coniferous wood, particularly silver fir. Oakwood is heavier than silver fir and has a less regular stem, especially in the case of trees from the Apennines. However, oak is stronger, harder, and much more durable than fir. These characteristics made oak less suitable for providing long roof beams or roof trusses but perfect for all kinds of foundations in contact with the ground (Bernabei et al., 2019).

Unsustainable wood harvesting can lead to forest degradation, deforestation, wood shortage, and a loss of forest ecosystem services, such as soil protection and water regulation (Janssen et al., 2017). In Pliny's time ( $1^{\text {st }}$ century AD), some of Algeria's forests rich in sandarac trees (Tetraclinis articulata), a wood particularly appreciated by the Romans, had already been fully exploited so that its timber supply shifted to Morocco (Bernabei et al., 2019). Emperor Hadrian created an imperial forest by fencing off the cedar of Lebanon woodland and marking its perimeter with inscribed boundary stones, to protect the woods (Shackley, 2004). In a sustainable system, the wood harvest is lower or equal to the production of wood within a certain area and time frame. In the case study of 
the ancient town of Sagalassos (South-west Anatolia, Turkey) during the Roman Imperial period, it could be concluded that its community was intensively using the surrounding forests (Janssen et al., 2017). According to palynological data, a steady forested area was sustained, suggesting an intensive but non-depleting use. This can only suggest that after a period of deforestation there must have been regulations for wood felling in later Roman periods, at least from $2^{\text {nd }}$ century.

\section{DISCUSSION}

\section{Regulations of wood felling in early modern} history

After the Treaty of Karlowitz in 1699, the Habsburg Monarchy gained control of territories between the Drava, Sava, and the Danube rivers, which were very rich in alluvial, flood plain forests. It was an area with an extremely low population and a low level of cultivation and amount of agricultural land (Radošević, 2019). During the following few centuries, the forests had time to recover themselves. However, the increasing population led to a rapid depletion of wood in the Croatian part of the Military Frontier (Cik, 2016).

Trees grow very slowly and are consumed very quickly. The selective felling of certain species of trees can lead to a change in the structure of the remaining forests. An oak tree needs 150-200 and beech 120 years to mature. Austrian imperial authorities were fully aware of this problem. For an improved hold on and control of these forest resources, the Habsburg administration brought forth various regulations and imperial decrees. According to a forest regulation document for the Military Frontier in today's Croatia, from the $18^{\text {th }}$ century, the use of oak for the construction of public buildings was prohibited (Cik, 2016):

"Until now, it was customary that all imperial buildings, schools, and churches were built only of oak wood, which is why, on the one hand, the forest was shrinking, and on the other hand, such material, due to its weight, damaged the buildings. As these buildings must be made of quality wood, everything except the roof must be built of white wood, i.e. beech, ash, and hornbeam. By no means should oak be used for the lower part of buildings, except those erected on wet and damp terrain, but the mentioned types of wood." Waldordnung (Schumske Uredbe Za Cesarsku Kraljevsku kraicsnicsku Schumu, Slavnoske, Varasdinske i Banalske Kraine) Wilhelm Ludwig Gustav von Wartensleben, Generalmajor, in Wien 24. 4. 1787.

\section{Beechwood use}

In Pompeii, beech was largely used as firewood (Veal and Thompson, 2008). Despite being considered good firewood in Roman times, the growing number of beechwood finds in recent years proves its use as an important building material in various timber structures. Its advantage over other timber, e.g. oak, is its large, regular stem and the fact that it is lighter than oak.

Beech trees can grow to be 300 years old or more, although trees between 100 and 140 years old are typically felled. They can reach a height of 30 to 35 metres. The colour of Beechwood varies from nearly white to reddish. It is resistant to abrasion but susceptible to attack by fungi and needs to be protected if used outdoors. With about 250 known uses for its wood, beech is the most diversely used tree species in Europe (von Wühlisch, 2003). While it is mainly used for furniture, it is also excellent for flooring and staircases. It is used as a fuel due to its relatively high energy content. Despite its hardness, Beechwood can be worked easily, although because of its prolonged drying process, there is considerable degradation due to its relatively high shrinkage rate. It is subject to movement more than other woods and is very sensitive to moisture. Beechwood easily steam-bends, a process through which it acquires a reddish-brown colour. Beechwood has a very wide range of uses and is used for relatively low and tall 
constructions, for stairs, etc. Beechwood has been favoured for plane stocks from Roman times to the modern era (Ulrich, 2007). The durability of beech under variable conditions is relatively small, while its durability underwater and on dry land is high.

Dendroarchaeological investigation of Roman ship wrecks in Croatia has revealed that they were built of multiple tree species (Huguet et al., 2012; Liphschitz et al., 2017; Liphschitz and Gluščević, 2015), with the keel most often made of common beech (Fagus sylvatica). Theophrastus (Hist. Pl. 5.8.3) recognised beech as one of the most notable and useful trees of Italy's Latium; he noted that timbers of beech would be most suitable for the keels of ships but also household furniture, such as bedsteads (5.6.4).

Researchers at Herculaneum (Moser et al., 2018) argue that the low percentage of beech timber discovered there is in keeping with its technological properties: its tendency to break and bend makes it somewhat unsuitable for timber production. On the other hand, they speculate that one of the criteria followed in selecting the taxa for building purposes seems to be the availability of the trees in the neighbouring forests. However, the nearest beech forests, if we exclude the beech forests in today's Romania, or the Vršac mountains in Banat, were ca. $50 \mathrm{~km}$ from Viminacioum by air (Fig. 1). Finds at Herculaneum suggest that Fagus sylvati$c a \mathrm{~L}$. was used for poles and planks (Moser et al., 2018). This is not surprising, given the tendency for straight growth and beech's height. Moreover, these timbers can be easily cut with a saw and are thus very useful for the production of planks.

\section{Hornbeam}

After beech, hornbeam wood is the second most numerous in the assemblage from the Viminacium amphitheatre. The White Beech or Hornbeam (Carpinus betulus L.) belongs to another botanical family and has quite different properties than beech. In Serbia, common hornbeam occurs as an admixed tree species in forest types that are defined in the complex of common oak forests, in forest types of the Hungarian oak and Turkish oak belt, the sessile oak belt, and up to the forest types in the beech belt (Banković and Ranković, 2009).

Hornbeam wood, compared to oak and beech wood, is of poorer quality and less utilised. It has a twisted trunk and smooth bark. However, due to the higher utilisation of wood and to the reduction of the growing stock of valuable coniferous and broadleaf species, the use of hornbeam wood will be increasingly greater, i.e. this tree species is going to have an increasingly greater significance in the future (Karadžić, 2011). In Serbia, forests of hornbeam, generally, present a forestry problem. Its dominant coppice origin, aggressiveness, and invasion into the sites of other, more valuable, tree species (common oak, sessile oak, Hungarian oak, beech, etc.) lead to a complete stifling of the latter (Banković and Ranković, 2009).

\section{Ash}

In Serbia, there are four native species in the genus Fraxinus: flowering ash (F. ornus L.), common ash (F. excelsior L.), narrow-leaved ash ( $F$. angustifolia Vahl.), and Balkan ash (F. pallisae Willmott) (Cvjetićanin et al., 2014). They form pure and mixed forests (mainly with common oak), which are conditioned by additional moisture or high levels of underground water. Common ash and narrow-leaved ash are very closely related and have such a similar appearance that they are sometimes difficult to distinguish, especially when they are growing in mixed stands. There are reports of hybridisation in areas where they occur together, e.g. in the Balkans (Boshier and Oxford Forestry Institute, 2005).

In Serbia, F. angustifolia Vahl. is distributed in the region of Pannonia and in river valleys, where it has probably been preserved thanks to the effect of the water bodies (Cvjetićanin et al., 2014). Common ash does not grow in the Pannonian Basin (Boshier and Oxford Forestry Institute, 2005).

Common ash and, to a lesser extent, nar- 


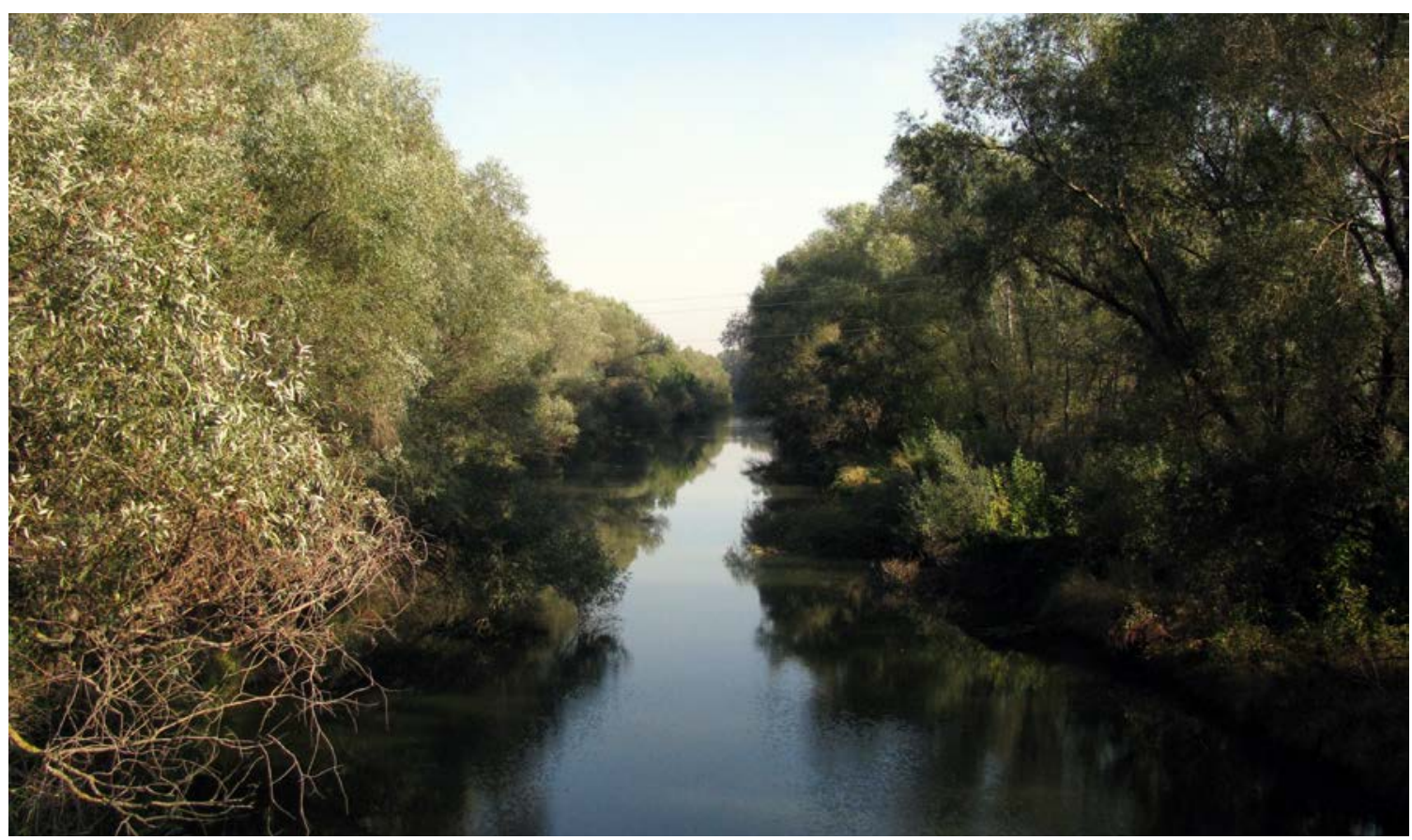

Fig. 2. Mlava river just before its confluence with the Danube river. (Photo: A. Medović)

row-leaved ash produce good quality timber, which is suitable for use for furniture and flooring (Boshier and Oxford Forestry Institute, 2005). F. excelsior L. is an important timber species, with attractive pale (white or pinkish white) wood that is strong, durable, resilient and easily bent, making it particularly suitable for furniture and house interiors. The strength and elasticity of the wood enable it to carry weight, bear tension and absorb shock better than any other European wood. Before the extensive use of steel, it was used for joists and beams, and many things now made of metal were originally made from ash, such as spears, ploughs, harrows, and rakes, as well as carriages, cart axles, the rims of cartwheels, and frames for boats and cars. The best timber for all these purposes comes from rapidly-grown trees on fertile sites. Timber with 4 to 16 rings of $25 \mathrm{~mm}$ is likely to be suitable for most purposes.

\section{Experiences from a carpentry workshop}

In terms of durability, wood is divided into groups: very durable wood (oak), durable wood (ash), and not durable wood (beech, maple, hornbeam). The greatest durability is shown by the wood prepared in a dry room, in low temperature without the presence of air. A tree that is constantly submerged in water also shows great durability. The lowest degree of durability is shown by wood used in the surface layer of the soil. Ashwood is very elastic, while beech and oak wood has a medium elasticity. The plasticity of wood increases from maple wood towards ash and beech wood. Beech, oak, maple, and ash wood have a stronger gloss than hornbeam. False heartwood (a wood defect caused by fungi) is common in beech, maple, ash, and hornbeam.

The occurrence of charred branches $(1.5-3 \mathrm{~cm}$ diameter) in the charred wood assemblage at the Viminacium amphitheatre may be interpreted as wood dowels or pegs. Ancient carpenters used wooden pegs instead of nails, and doweling has been used for centuries by carpenters who needed to strengthen their joints. There are a large number of joints in the trestle structures of the Viminacium amphitheatre. A good example of the joining of wooden parts without nails is a wooden mining 
tool made of beech wood from the $13^{\text {th }}-14^{\text {th }}$ century that was found at the archaeological site of Prilovi, Rudnik, in Serbia (Đorđević, 2011).

\section{Transport of timber}

Timber was transported over long distances within and between Roman provinces. There is evidence of the trade of high-quality timber, e.g. Picea abies (L.) Karst. (Moser et al., 2013), Quercus (Bernabei et al., 2019), but the Romans mainly used local resources (Čufar et al., 2014; Moser et al., 2013).

A dense network of waterway trade routes was intensively used to connect the Roman Empire (Bernabei et al., 2019). A flat-bottomed barge, at least $16 \mathrm{~m}$ long, was found in the Ljubljanica river, Slovenia (Čufar et al., 2014), which was probably used for transporting heavy cargo on the Ljubljanica river between the Roman settlements of Nauportus and Emona during the first decades AD. The bottom and side planks of the barge were made of beech wood (Fagus sylvatica). Use of beech wood, which has good mechanical properties but very low resistance against decay organisms.

It can be assumed that beech was chosen to construct the barge due to the massive availability of this species in the local forests in the area and the lack of oak (Čufar et al., 2014). Due to the great demand for timber during the Roman period, the available oak was probably not enough to meet all the needs. Other species, such as beech, were therefore used instead.

The beech timber came, most likely, from the Serbian part of the Carpathian Mountains, e.g. Homolje mountains (962 masl). The timber was transported by road or rafted and floated downstream on the rivers Mlava (Fig. 2) or Pek up to Viminacium, with the dimension and weight of the beech planks suggesting river rather than land transport. The other area from where beech trees could have been felled are the mountains next to the Iron Gates of the Danube.

\section{CONCLUSION}

Access to sufficient supplies of wood was a vital part of strategic readiness in ancient times. Some situations required wood with specific characteristics. Such specialised requirements stimulated, in the case of ancient Rome, exports of high-quality construction timber from Central Europe to Rome. Forest resources were overused to supply, for example, timber for construction, e.g. military ships, houses, and energy. The cyclical expansion and decrease of forests in the region of today's Serbia are directly related to the increase and decrease of the population through the centuries. In times of prosperity, the forests were heavily cut as a direct result of the recolonisation and increased demand for agricultural land. In a few extreme cases, war has helped forests by allowing ecosystems to recover free from human pressure.

The choice of supposedly less valuable construction timber for the Viminacium amphitheatre raises more questions than answers. Was oak scarce in the area at that time, and/or was it destined for Rome? Did the imperial officials in the provinces and the army, therefore, have to cover their needs with supposedly less valuable wood for construction, as was the case in the Slavonian Military Frontier in the $18^{\text {th }}$ century? Or, were the selection criteria of lighter wood and longer timber crucial for the choice of building materials for construction?

The fact that the Viminacium amphitheatre typologically belongs to Golvin's simplest type of amphitheatre indicates that a second-best construction timber was chosen for its construction, while on the other hand, a large, complex structure that was built on the principle of the trestles indicates that lighter and longer timber had to be used for its construction. Beechwood meets both these conditions. 


\section{BIBLIOGRAPHY}

\section{Banković, S., Ranković, N. (Eds.) 2009}

The national forest inventory of the Republic of Serbia: the growing stock of the Republic of Serbia. Ministry of Agriculture, Forestry and Water Management of the Republic of Serbia-Forest Directorate Belgrade, Belgrade.

Bernabei, M., Bontadi, J., Rea, R., Büntgen, U., Tegel, W. 2019

Dendrochronological evidence for long-distance timber trading in the Roman Empire. PLoS ONE 14, e0224077. https://doi.org/10.1371/journal. pone. 0224077

\section{Bogdanović, I., Nikolić, S. 2017}

In the Beginning There Was a Timber Construction ... The Wooden Amphitheatre of Viminacium, in: Mitthof, F., Schörner, G. (Eds.), TYCHE Sonderband. Presented at the Columna Traiani Traianssäule Siegesmonument und Kriegsbericht in Bildern, Holzhausen, Wien, pp. 87-94.

Boshier, D. (Ed.) 2005

FRAXIGEN: Ash species in Europe: biological characteristics and practical guidelines for sustainable. Oxford Forestry Institute, Oxford.

\section{Cik, N. 2016}

Ekohistorija Đurđevca $i$ Virja u drugoj polovici 18. stoljeća. Meridijani, Društvo za hrvatsku ekonomsku povijest i ekohistoriju, Ogranak Matice hrvatske u Đurđevcu, Samobor-Zagreb-Đurđevac.

\section{Čufar, K., Merela, M., Erič, M. 2014}

A Roman barge in the Ljubljanica river (Slovenia): wood identification, dendrochronological dating and wood preservation research. Journal of Archaeological Science 44, 128-135. https://doi. org/10.1016/j.jas.2014.01.024

Cvjetićanin, R., Šijačić-Nikolić, M., Milovanović, J., Perović, M., Novaković-Vuković, M. 2014
Regions of provenances of Fraxinus angustifolia Vahl. and Fraxinus pallisae Wilmott in Serbia. Шумарство (Šumarstvo) 3-4, 131-142.

\section{de Lamartine, A. 1843}

Voyage en Orient, 1832-1833. C. Gosselin, Paris.

\section{Demian, J.A. 1807}

Darstellung der Oesterreichischen Monarchie nach den neuesten statistischen Beziehungen: Statistische Beschreibung der Militär-Gränze; Bd. 2, welcher die Militär-Gränze in Slavonien und Ungern enthält. Wien.

Food and Agriculture Organization of the United Nations 1995

State of the world's forests. FAO, Rome.

Fukarek, P., Jovanović, B. (Eds.) 1983

Karta prirodne potencijalne vegetacije SFR Jugoslavije 1:1000000. Naučno veće vegetacijske karte Jugoslavije, Šumarski fakultet Univerziteta Kiril i Metodije u Skopju, Skopje.

\section{Golvin, J. C. 1988}

L'amphithéâtre romain : Essai sur la théorisation de sa forme et de ses fonctions. Diffusion de Boccard, Paris.

\section{Halpern, J. 1999}

The ecological transformation of a resettled area, pig herders to settled farmers in Central Serbia (Sumadija, Yugoslavia) during the 19th and 20th centuries, in: Greenfield, H.J., Bartosiewicz, L. (Eds.), Transhumant Pastoralism in Southern Europe: Recent Perspectives from Archaeology, History, and Ethnology. Archaeolingua, Budapest, pp. 79-95.

Huguet, C., Capelli, C., Guibal, F., Greck, S., Cenzon-Salvayre, C., Andrieu-Ponel, V., Dumas, V. 2012

L'épave de Pakoštane, Croatie (fin IVe -début Ve siècle apr. J.-C.). Résultats d'un projet de recherche franco-croate. Archaeonautica 17, 105-151. 
https://doi.org/10.3406/nauti.2012.1255

Janssen, E., Poblome, J., Claeys, J., Kint, V., Degryse, P., Marinova, E., Muys, B. 2017

Fuel for debating ancient economies. Calculating wood consumption at urban scale in Roman Imperial times. Journal of Archaeological Science: Reports 11, 592-599. https://doi.org/10.1016/j. jasrep.2016.12.029

Kabukcu, C. 2018

Wood Charcoal Analysis in Archaeology, in: Pişkin, E., Marciniak, A., Bartkowiak, M. (Eds.), Environmental Archaeology. Springer International Publishing, Cham, pp. 133-154. https://doi. org/10.1007/978-3-319-75082-8_7

\section{Liphschitz, N., Gluščević, S. 2015}

The Zaton Boat 2 (Croatia). A Dendroarchaeological Investigation. Skyllis 15, 158-160.

Liphschitz, N., Radić Rossi, I., Pulak, C., Ruff, D. 2017

The Roman ship found at Trstenik (Gulf of Kaštela, Croatia). The determination of wood species. Skyllis 148-152.

\section{Marguerie, D., Hunot, J.-Y. 2007}

Charcoal analysis and dendrology: data from archaeological sites in north-western France. Journal of Archaeological Science 34, 1417-1433. https://doi.org/10.1016/j.jas.2006.10.032

\section{Medović, A. 2014}

Viminacium: Roman Agriculture on Serbian Soil? Archaeology and Science 9, 95-99.

Moser, D., Allevato, E., Clarke, J.R., Di Pasquale, G., Nelle, O. 2013

Archaeobotany at Oplontis: woody remains from the Roman Villa of Poppaea (Naples, Italy). Vegetation History and Archaeobotany 22, 397408. https://doi.org/10.1007/s00334-012-0381-z
Moser, D., Nelle, O., Di Pasquale, G. 2018

Timber economy in the Roman Age: charcoal data from the key site of Herculaneum (Naples, Italy). Archaeological and Anthropological Sciences 10, 905-921. https://doi.org/10.1007/s12520-0160406-0

\section{Moser, D., Nelle, O., Di Pasquale, G. 2011}

The Romans, the wood and the forest: state of the art and new data from the Vesuvius area (Naples, Italy), in: SAGVNTVM Extra. Presented at the 5th International Meeting of Charcoal Analysis: The charcoal as cultural and biological heritage, UNIVERSITAT DE VALÈNCIA Departament de Prehistòria i Arqueologia de la Facultat de Geografia i Història, Valencia, pp. 113-114.

\section{Radošević, M. 2019}

Šume i društvo Slavonske vojne krajine: primjer Brodske pukovnije u drugoj polovici 18. i početkom 19. stoljeća. Scrinia Slavonica 19, 93-128.

Schoch, W., Heller, I., Schweingruber, F., Kienast, F. 2004

Wood anatomy of central European Species. URL www.woodanatomy.ch (accessed 12.7.20).

\section{Schweingruber, F.H. 1990}

Mikroskopische Holzanatomie: Formenspektren mitteleuropäischer Stamm-und Zweighölzer zur Bestimmung von rezentem und subfossilem Material = Anatomie microscopique du bois = Microscopic wood anatomy, 3. Aufl. ed. Flück-Wirth, Teufen.

\section{Shackley, M. 2004}

Managing the Cedars of Lebanon: Botanical Gardens or Living Forests? Current Issues in Tourism 7, 417-425. https://doi. org/10.1080/13683500408667995

\section{von Wühlisch, G. 2003}

Technical Guidelines for genetic conservation and use for European beech (Fagus sylvatica). Bioversity International, Rome. 
Vukin, M., Rakonjac, Lj. 2013

Comparative analysis of some bioecological characteristics of Hungarian oak and Turkey oak. Archives of Biological Sciences 65, 331-340. https:// doi.org/10.2298/ABS1301331V

\section{Карашић, Д. 2011}

Најчешће паразитске и сапрофитске гљиве на грабу (Carpinus betulus L.) у Србији и њихова улога у пропадању стабала. Шумарство 1-2, $1-12$.

(Karadžić, D. 2011. Najčešće parazitske i saprofitske gljive na grabu (Carpinus betulus L.) u Srbiji i njihova uloga u propadanju stabala. Šumarstvo $1-2,1-12$.)

Цвјетићанин, Р. 2003

Фитоценозе букве у Србији. Шумарство 1-2, 107-112.

(Cvjetićanin, R., 2003. Fitocenoze bukve u Srbiji. Šumarstvo 1-2, 107-112.)

\section{Ђорђевић, 3. 2011}

Конзерваторски третман рударске алатке са Рудника. Зборник радова Музеја рудничкотаковског краја 6, 229-235.

(Đorđević, Z., 2011. Konzervatorski tretman rudarske alatke sa Rudnika. Zbornik radova Muzeja rudničko-takovskog kraja 6, 229-235).

\section{REZIME DA LI SE ISTORIJA PONAVLJA? ANALIZA DRVNE GRAĐE AMFITEATRA U VIMINACIJUMU}

KLJUČNE REČI: VIMINACIJUM, RIMSKI PERIOD, AMFITEATAR, DRVENA, KONSTRUKCIJA, ANTRAKOLOGIJA.

Amfiteatar $u$ Viminacijumu izgrađen je uglavnom od bukovog drveta. Osim toga, pri izgradnji je korišćena drvna građa od graba, jasena, javora, hrasta, ali i četinara. Smatra se da je bukovina u rimskom periodu bila potcenjena i da se uglavnom koristila kao drvo za ogrev. Nedavna antrakološka istraživanja u regionu otkrila su upotrebu bukovine u brodogradnji. U Rimu je bio dostupna širok spektar drvne građe. Međutim, velika potražnja za drvetom u Rimu dovela je do brzog iscrpljivanja šuma u okolini, a potom i na Apeninskom poluostrvu. Carstvo se širilo, a seča drveća je nastavljena širom carstva. Drvo se transportovalo na velikim razdaljinama, unutar i između rimskih provincija. Hrastovo drvo imalo je ogromnu vrednost ne samo u rimskom periodu, već i kroz čitavu istoriju. Hrastova građa je bila izuzetno cenjena. Prekomerna seča hrasta navela je austrijsku vlast vojne krajine da krajem 18. veka izda šumsku uredbu o zabrani upotrebe hrastove građe za izgradnju javnih zgrada. Uredba ukazuje, s jedne strane, da je selektivna seča hrastovih stabala dovela do promene $\mathrm{u}$ strukturi preostalih šuma u regionu i da je dovela do smanjenja šumskog fonda, a, s druge strane, hrastova građa je, zbog svoje težine, uticala na oštećenja izgrađenih objekata. U uredbi se navodi da nove građevine moraju da budu izrađene od kvalitetnog drveta, te da sve osim krovnih konstrukcija mora da bude izgrađeno od tzv. „belog drveta“, odnosno bukve, jasena i graba.

Arheologija i prirodne nauke (Archaeology and Science) is an Open Access Journal. All articles can be downloaded free of charge and used in accordance with the licence Creative Commons - Attribution-NonCommercial-NoDerivs 3.0 Serbia (https://creativecommons.org/licenses/bync-nd/3.0/rs/.

Casopis Arheologija i prirodne nauke je dostupan u režimu otvorenog pristupa. Članci objavljeni u časopisu mogu se besplatno preuzeti sa sajta i koristiti u skladu sa licencom Creative Commons - Autorstvo-Nekomercijalno-Bez prerada 3.0 Srbija (https://creativecommons.org/licenses/bync-nd/3.0/rs/. 